\title{
Adopting Organizational Structuring for ICT-enabled Government Transformation: Perspectives of City Government Employees in Indonesia and the Philippines
}

\author{
Enrique B. Batara \\ Doctoral Program Political Science \\ Universitas Muhammadiyah Yogyakarta \\ Yogyakarta, Indonesia \\ enrique.batara@g.msuiit.edu.ph
}

Abstract - e-government or the use of ICT and its application by the government for the provision of information and public services to the people is now the norm. Local governments, being at the frontline of public service delivery, have to keep up with e-government practice and development in order to satisfy the imperatives of good governance. A framework of transformational government identifies elements which are interrelated and are consequential to the utilization of new ICT systems: process redesign; organizational structuring; and, cultural and behavioral change. Using variables fetched from various technology acceptance models, this study investigates the factors for the adoption of organizational structuring by city government employees in the city governments of Surabaya, Indonesia and Davao, Philippines. Survey data gathered from 78 Surabaya and 82 Davao purposively-sampled employee respondents was quantitatively analyzed through structural equation modeling. It was found out that performance expectancy and attitude are the pivotal factors in influencing the intention of adopting organizational structuring. Moreover, age and length of work experience of the city government employees appear to have limited relevance as moderating variables.

Keywords - local $\quad \begin{aligned} & \text { government, } \\ & \text { government, }\end{aligned}$
$\begin{aligned} & \text { transformational } \\ & \text { organizational structuring }\end{aligned}$

\section{INTRODUCTION}

As a result of the advancement in information and communication technology (hereafter referred to as ICT), delivery of services to citizens is now by e-government. E-government or the use of ICT and its application by the government for the provision of information and public services to the people [1] is now the norm. In fact, as of 2014, e-government is practiced in all 193 member-states of the United Nations [2]. Such was the pace of the adoption mode of state bureaucracies. And this has trickled down to the lower bureaucratic levels. Local governments, being at the frontline of public service delivery, had to keep up with egovernment practice in order to satisfy the imperatives of efficiency, effectiveness, social inclusion and transparency in governance ([3], [4], [5]).

While some states are still in the stage of adaptation and adoption of the technology, others are already in the stage of transformation. According to a 2012 United Nations report, "with public sectors offering an increased number of services, the focus is shifting from what kinds of services are provided to how they are provided" $[6, \mathrm{p}$. 85]. Undoubtedly, e-government is now a worldwide bureaucratic feature. At present, the 'how' is basically the use of ICT systems. While technological changes such as new hardware and software and media may not be difficult to keep abreast with, there are related elements in the bureaucratic organization that need to be transformed as well. In a proposed framework of 
transformational change [7], three other elements are identified, all of which are interrelated and are consequential to the utilization of new ICT systems: process redesign; organizational structuring; and, cultural and behavioral change. These are subsumed under two concepts which have been prominent in many scholarly works on e-government: integration and transformation ([8], [9], [10], [11], [12], [13], [14]).

E-government development is one plausible indicator that it is on the path of transforming into the way it should be practiced, designed and fitted to a state's context. The UN has, for a period covering eight years, surveyed and measured its member states using the e-government development index or EGDI [15]. This framework placed importance on three dimensions: availability of online services; telecommunication infrastructure; and human capacity. Generally, the series of findings show how a state has fared egovernment-wise in terms of development and participation. Viewed simply, it tells a state's current state of e-government relative to other states, and a world region relative to other regions. Table 1 below shows the status of Southeast Asian states' egovernment development according to the latest survey [16].

TABLE 1. 2014 E-GOVERNMENT DEVELOPMENT INDEX (EGDI) WORLD RANKING AND LEVEL OF SOUTHEAST ASIAN STATES

\begin{tabular}{|l|c|c|}
\hline \multicolumn{1}{|c|}{ State } & $\begin{array}{c}\text { Rank (out of } \\
\text { 193 states) }\end{array}$ & Level \\
\hline Singapore & 3 & Very High \\
\hline Malaysia & 52 & High \\
\hline Brunei & 86 & High \\
\hline Philippines & 95 & Middle \\
\hline Vietnam & 99 & Middle \\
\hline Thailand & 102 & Middle \\
\hline Indonesia & 106 & Middle \\
\hline Cambodia & 139 & Middle \\
\hline Laos & 152 & Middle \\
\hline Myanmar & 175 & Low \\
\hline
\end{tabular}

The data shows how the Southeast Asian states have progressed in relation to other states in terms of e-government development. Of particular interest to this study are the states of Indonesia and the
Philippines. Both states have scored on the index corresponding to the 'middle' level. The implications of these findings could be best appreciated in view of the suggestion that "with clear strategies, smart investment in ICT infrastructure, continued investment in primary, secondary and tertiary education, as well as through radical transformation in offering online public services, governments can achieve more to follow the upward trend" [17, p. 16].

It is therefore important to know what could account for Indonesia's and Philippines' present e-government state and what variables, aside from the UN index, could be pivotal for the 'transformation' necessary for development and to 'follow the upward trend' in e-government. Of course, any attempt to examine this at the state level would be a huge task. However, examining a whole through its parts could facilitate in shedding light to the larger picture.

The study of e-government development and transformation factors has been pursued by individual scholars and organizations ever since e-government was utilized by states. Two studies on a global scale highlight crucial factors in the transformation of e-government. According to the UNDESA [18], transforming government through a 'whole-ofgovernment' approach require the following enabling factors: a) new forms of collaborative leadership and shared organizational culture manifested by reshaped values, mindsets, attitudes and behaviors; b) new forms of institutional frameworks for effective coordination, cooperation and accountability across government, between governments and with relevant non-public actors; c) innovative coordination processes and mechanisms, which are inclusive and accessible, for service delivery, and citizen engagement and empowerment; d) citizen- and user-centric collaborative mechanisms to engage citizens in service delivery and decision-making; and, e) appropriate ICT management 
strategies in harnessing the power of new technology for enhanced collaboration.

A longitudinal study of the world's e-governments, for a period spanning a decade, by the Waseda UniversityInternational Academy of Chief Information Officers (or Waseda-IAC) ranks egovernments utilizing nine main indicators: network preparedness /infrastructure; management organization /efficiency; online services/functioning applications; national portal/homepage; government chief information officer (CIO); e-government promotion; e-participation/digital inclusion; open government; and, cyber security [19]. The study's findings point out certain factors that explain the e-governments' development or lack thereof which include: a) the lack of ICT human resources, especially CIOs, development and capacity building; b) key for success of e-government projects is enough funding or financial resources; c) more encouragement of citizen engagement as digital inclusion in egovernment initiatives; d) developed countries showcase progression of numerous online service applications; e) local egovernment issues must be given more attention; f) high usage of mobile devices may be taken advantage of for the practice of 'mobile-government'; g) implementation of 'open government' /'open data' and sharing with 'big data'; and, h) because the digital gap has become wider in terms of accessibility, usability, and affordability, ways to narrow down the gap must be put in place. Evidently, the two studies yield several common factors observed from egovernments worldwide which are essential for transformation.

Transforming

e-government

necessitates a broad range of changes in the bureaucratic environment. It must be cognizant of new available ICT systems and applications. Steps to improve or totally change designs of service processes must be done considering largely the demands of citizens and the maximum provision to them. Elements of the organization, both human (and their internal qualities) and structural, should be adaptable to change.

This study draws from the transformational change framework [20] which shows the process as moving from one state or situation ('as is') to another state or situation ('to be'). The 'to be' situation, as adapted from Hammer and Champy [21], should show basic developments and major change in the organizational structure, its culture, and processes driven by the introduction of new ICT in order to realize actual government transformation. This study is motivated by the idea and practice of e-government transformation as defined by the following constructs: new ICT systems; process redesign; organizational structuring; and, cultural and behavioral change [22]. This study focuses on organizational structuring as one of the characteristics of transformational government.

In transforming e-government, organizational structuring must be done in the following ways: establishment of ICT department; institutionalizing professional leadership and management of ICT through Chief Information Officer/Chief Data Officer; shifting of back-office activities to front-office; and vigorous human resource training and re-tooling ([23], [24], [25], [26], [27], [28], [29]).

Whether e-government is adopted or not by stakeholders in society is one question that has challenged many scholars. In e-government adoption literature, a wide range of theories and models have been used to determine which variables could account for the adoption and use of e-government by different stakeholders. In Appendix 1, recent scholarly works indicate that much attention has been focused on the adoption of egovernment services and systems, and data have been collected mostly from citizenusers. There is a need for research which shall focus on other essential e-government aspects and stakeholders. To fill this gap, this study focuses on the intention of local government employees, a less-studied 
population, to adopt practices and activities essential for e-government transformation.

\section{A. Research Objectives}

This study utilizes a research model that could: a) determine the associations of variables in the adoption of organizational structuring; and, b) determine which variables are pivotal in the adoption of organizational structuring from the perspective of city government employees in the cities of Surabaya, Indonesia and Davao, Philippines. Drawing from adoption models and theories, this research sought to answer the following questions: 1) how are performance expectancy, effort expectancy, social influence, facilitating conditions, anxiety, and attitude associated with the intention of adopting organizational structuring by local government employees in both cities? and, 2) how do age and length of work experience in the organization moderate these associations?

\section{B. Significance of the Study}

Aside from contributing to the research-based knowledge on e-government, this research is important for a number of reasons. Firstly, results can draw up practical implications to the cities in developing and transforming their respective e-government. Also, data from the research respondents could guide the appropriate authorized person/s or organization in crafting programs and strategies to thrust egovernment further upward. Moreover, agencies mandated to support or build the capacity of local bureaucracies could understand and value the need for continuous transformational change.

In the literature, there is a lack of information on e-government change or transformational government from the use and adoption perspective. Also, as observed, although several theories and models have been developed and utilized to analyze egovernment adoption, such theories have not been extensively used from an employee perspective [30]. This study could, therefore, contribute to building up research-based knowledge in these aspects. Furthermore, this could generate more interest to conduct research on transformational government, or other concepts subsumed under egovernment, among other researchers and students of politics, public administration and technology.

\section{Conceptual and Theoretical Framework}

This study is anchored on three theories of technology acceptance: the unified theory of acceptance and use of technology (UTAUT); the theory of reasoned action (TRA); and, social cognitive theory (SCT). Select core constructs are drawn from these theories to compose the linear regression model for this study. The UTAUT [31] consists of four main constructs: performance expectancy (PE), effort expectancy (EE), social influence (SI) and facilitating conditions (FC), which are variables hypothesized to influence the dependent variables behavioral intention (BI) and technology usage (TU). Behavioral intention is seen as a critical predictor of technology use. Gender, age, experience and voluntariness of use are moderating variables hypothesized to influence on behavioral intention by the independent variables. The range of technologies, application scenarios, and geographical settings for which technology adoption has been studied validates the generalizability of UTAUT's core constructs ([32], [33], [34]).

Attitude is an important construct of the theory of reasoned action (TRA) which theorizes that 'attitude' towards an innovation is hypothesized to be determined by the users' perceived usefulness and perceived ease of use [35]. Both the TRA and TAM (theory of acceptance model) argue that, all other conditions constant, individuals execute behaviors towards which they have a positive affect [36]. In the TPB (theory of planned behavior) model, Ajzen [37] proposes that attitude towards behavior 
is generally found to precisely predict the individual's behavioral intentions.

This study also employs the social cognitive theory (SCT) as applied by Compeau and Higgins [38]. In particular, this study took the SCT construct anxiety and made it as a predictor variable, taking into consideration that the model permits it to cover the study of technology acceptance and use in general.

Performance expectancy is defined as the extent to which a person believes that using a system will help him or her to attain gains in job performance and it is a strong predictor of intention to use technology in voluntary scenarios (Venkatesh et al. 2003) and satisfaction with technology in mandatory settings (Chan et al. 2010). Although the extant literature on performance expectancy as a predictor of egovernment adoption is prolific, its role as predictor of other e-government dimensions is scantily studied. In this study, performance expectancy is the extent to which a person believes that adopting organizational structuring will help him or her to attain gains in job performance.

H1. Performance expectancy is positively associated with intention to adopt organizational structuring.

Effort expectancy is defined as the degree of ease associated with the use of the system [39]. On a conceptual level, Carter and Belanger [40] argue that citizens' intentions to use a state e-government service will increase if citizens perceive the service to be easy to use, while Stamati et al. [41] posits that perceived ease of use (measured as effort expectancy) will have a positive effect on the behavioral intention to adopt transformational government citizens' services. Even though effort expectancy has been steadily observed as a predictor of egovernment adoption, as well as of other technology platforms, its role as transformational government adoption predictor remains under-investigated. As used in this study, effort expectancy is the degree of ease associated with adopting organizational structuring.

H2. Effort expectancy is positively associated with intention to adopt organizational structuring.

Social influence is defined as the degree to which an individual perceives that important others believe that he or she should use the new system [42]. While a lot of studies confirm that social influence significantly affects intention to adopt egovernment and other ICT systems, studies need to be done in order to test it as a predictor of e-government transformation. In this study, social influence is the degree to which a respondent perceives that significant others believe that he or she should adopt organizational structuring.

H3. Social influence is positively associated with intention to adopt organizational structuring.

Facilitating conditions are defined as the degree to which an individual believes that an organizational and technical infrastructure exists to support the use of the system [43]. Despite the fact that facilitating conditions have significant effects on use intention and actual use of technology in government, its effects on intention to adopt transformation in e-government ought to be examined too. As used in this study, facilitating conditions are the degree to which a respondent believes that an organizational and technical infrastructure is available to support the adoption of organizational structuring.

H4. Facilitating conditions are positively associated with intention to adopt organizational structuring.

Even though extensive research has been done on anxiety in the fields of psychology and information systems, its role as a predictor of behavioral intention in the context of e-government adoption and 
transformation has not been substantially investigated. In this study, anxiety is the city government employee's apprehension or fear when he or she is faced with the possibility of adopting organizational structuring.

H5. Anxiety is negatively associated with intention to adopt organizational structuring.

Attitude towards behavior is defined as the degree to which an individual makes a favorable or unfavorable evaluation or appraisal of the behavior in question [44]. The relationship between attitude and behavioral intention have been presented in several studies ([45], [46], [47], [48]). Although attitude has been substantively shown through studies as meaningfully affecting adoption and use of various egovernment services, platforms and systems, it also has to be examined whether it is a predictor of transformational government adoption. As used in this study, attitude is defined as the degree to which a respondent makes a favorable or unfavorable evaluation or appraisal of adopting organizational structuring.

H6. Attitude is positively associated with intention to adopt organizational structuring.

Moderators are variables whose variation influences the strength or the direction of a relationship between an independent variable and dependent variable [49]. Moderator variables can either be metric (e. g., consumer psychological constructs like arousal or intelligence) or categorical (e. g., gender or social class) in nature [50]. The UTAUT model hypothesizes a moderating influence by age on the relationships among performance expectancy, effort expectancy, social influence, and behavioral intention to use technology and also on the relationship between facilitating conditions and usage behavior ([51], [52]). This study postulates that age of city government employees moderates the relationships between the independent variables (effort expectancy, anxiety and attitude) and intention to adopt organizational structuring.

H7a. Age will significantly moderate
the association between effort
expectancy and intention to adopt
organizational structuring. H7b. Age will significantly moderate the association between anxiety and intention to adopt organizational structuring.

H7c. Age will significantly moderate the association between attitude and intention to adopt organizational structuring.

There is a lack of knowledge in egovernment literature on the role of length of work experience in an organization. As Rana et al. [53, p. 419] have observed, "although the UTAUT is a unified model mapped created from eight established models of IS adoption research including the TAM (theory of acceptance model), the DOI (diffusion of innovation), and the TPB (theory of planned behavior), the UTAUT has not been widely used to analyze adoption of e-government services from an employee perspective". In view of this, this research includes length of work experience as a moderating variable for the basic reason that results will be extracted from local government employees, with the assumption that their work experience could influence their intentions towards adopting transformation in the workplace.

H8a. Length of work experience will significantly moderate the association between performance expectancy and intention to adopt organizational structuring.

H8b. Length of work experience will significantly moderate the association between effort expectancy and intention to adopt organizational structuring. 
H8c. Length of work experience will significantly moderate the association between social influence and intention to adopt organizational structuring.

H8d. Length of work experience will significantly moderate the association between attitude and intention to adopt organizational structuring.

This research uses a linear regression model (Fig. 1) wherein the independent variables performance expectancy (PE), effort expectancy (EE), social influence (SI), facilitating conditions (FC) anxiety (ANX) and attitude (AT) are hypothesized to be associated with the dependent variable behavioral intention (BI) of adopting organizational structuring. Age (AGE) and length of work experience (LWE) are proposed as moderating variables.

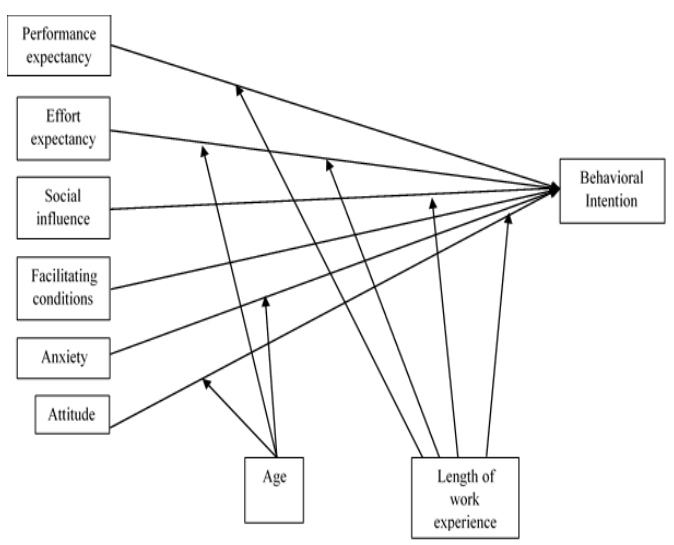

Fig. 1. Research model showing the hypothesized relationships between variables.

\section{METHOD}

This study surveyed government employees in Surabaya City, Indonesia and Davao City Philippines. Surabaya is Indonesia's second largest city, it is Indonesia's 'other' industrial heartland and metropolis next to Jakarta [54]. Surabaya is regarded as the leading 'digital city' in Indonesia since it has been awarded the Indonesia Digital Society Award (IDSA) in 2014 , evidenced by yearly increases in ICT spending which has been induced by the perceived benefits of giving greater attention to IT usage in providing citizen services [55]. In an e-government evaluation study of Indonesian cities, Surabaya came out firstranked in the index of reform (IR) based on the following parameters: citizen service, business permission, planning transparency and finance transparency [56]. Further, it has been found out that the e-government of Surabaya has a significant effect in moderating reliability on the city government, and has a strengthening characteristic to community satisfaction with the city's public services [57].

Davao City is the regional capital and largest city of Mindanao, Philippines [58]. Davao is deemed an interesting case of e-government transformation. The UNDESA [59] has cited the city as one of the examples of local portal features that are indicative of integration and transformation. Specifically, the UN study referred to the creation by the Davao Medical Center, as a result of gender and development mainstreaming efforts, of the Women and Children Protection Unit (WCPU) which is a one-stop family crisis intervention center that provides legal, psychiatric and medical services to its patients. This is line with the continuing transformation of the agency based on one of its transformation pillars: sound information technology, that is, the linking of systems and services using the most appropriate technology for their specific needs [60]. Moreover, Davao City is one of the cities in Southeast Asia which is developing a 'smart city' [61]. It is apparent that both cities show indicators of egovernment transformation, hence their selection.

The respondents of this study are the purposively-sampled employees of the governments of the two cities. A total of 120 questionnaires per city were distributed to the city government employees. In Surabaya, Indonesia, these were handed out to 23 agencies/offices. Out of 120, 78 valid questionnaires were retrieved. While in Davao, Philippines, 82 were retrieved out of 
120 questionnaires allocated to 12 departments/offices.

Data was gathered through a structured questionnaire. It consists of three parts: a) the first part to extract data for the variables age, length of work experience, and position in the organization; b) the second part explains the construct organizational structuring and identifies its operational meaning; and, c) the third part to draw responses on statements pertaining to the independent and dependent variables. A five-point Likert-type level of agreement scale [62] ranging from Strongly Disagree (1) to Strongly Agree (5) was used to measure responses on indicators of the constructs EE, PE, SI, FC, ANX, AT and BI (Appendix 2). Data was analyzed using licensed versions of IBM SPSS Statistics (version 19), and Smart PLS or Partial Least Square (version 3) for structural equation modeling tests.

\section{RESULTS AND DISCUSSION}

There is a notable difference between the Davao and Surabaya samples in terms of age. Although majority of the samples in both cities fall under the younger age brackets (21-45), more Surabaya employees belong to this group compared to the Davao employees. Conversely, while the minority of the samples in both cities fall under the older age brackets (46-65), more Davao employees fit in this group compared to the Surabaya employees. In terms of work experience in the city government, it appears that majority of the Davao employees have worked longer (11 years and more), while majority of the Surabaya employees have worked shorter (10 years and less). Samples from both cities consisted of a minority of department or division heads, and a large majority of staff-level employees, which is likely in the bureaucracy context. Table 2 below presents the demographic profile of this study's sample.

In assessing the relationships of the hypothetical constructs, regression weights should be significant at least at the .050 level ([63], [64]), and a weight or coefficient of at least .100 reports a certain impact within the structural model [65]. These are either positive (i.e. in the expected direction) or negative. Regression weight values of approximately $0.67,0.33$, and 0.19 are considered as substantial, moderate and weak, respectively, in terms of the level of explanatory power [66]. Table 3 below presents this analysis.

TABLE 2. DEMOGRAPHIC PROFILE OF SAMPLE (IN \%)

\begin{tabular}{|l|c|c|}
\hline \multicolumn{1}{|c|}{ Variable } & Davao & Surabaya \\
\hline Age bracket & & \\
\hline $21-35$ & 28 & 38.5 \\
\hline $36-45$ & 37.8 & 39.7 \\
\hline $46-55$ & 22 & 19.2 \\
\hline $56-65$ & 12.2 & 2.6 \\
\hline Length of work experience & & \\
\hline 0-5 years & 7.3 & 19.2 \\
\hline 6-10 years & 30.5 & 33.3 \\
\hline 11-15 years & 31.7 & 21.8 \\
\hline 16 years plus & 30.5 & 25.6 \\
\hline Position & & \\
\hline Department/Division head & 9.75 & 16.66 \\
\hline Staff & 90.25 & 83.33 \\
\hline
\end{tabular}

The tests for the regression weights between performance expectancy (PE) and behavioral intention (BI) showed that there is positive association between the two variables in both Davao and Surabaya, with regression weights of .151 and .353 respectively. Results also showed that there is no positive association between effort expectancy (EE) and behavioral intention (BI) in both cities. Likewise, there is no positive association between social influence (SI) and behavioral intention (BI), although there is a remarkable negative association between social influence and behavioral intention for Davao. Tests also showed that there is no positive association between facilitating conditions (FC) and behavioral intention (BI) in Davao and Surabaya. Anxiety (ANX) is not negatively associated with behavioral intention (BI) in both cities. Results showed that attitude (AT) is significantly associated with behavioral intention (BI) in Davao and Surabaya, with regression weight values of .862 and .421 respectively. 
TABLE 3. REGRESSION WEIGHTS AND HYPOTHESIS TESTING FOR

DAVAO (D) AND SURABAYA (S)

\begin{tabular}{|c|c|c|c|c|c|c|}
\hline \multirow[t]{2}{*}{ Relationship } & \multicolumn{2}{|c|}{$\begin{array}{l}\text { Standardized } \\
\text { regression } \\
\text { weight }\end{array}$} & \multicolumn{2}{|c|}{$\begin{array}{l}\text { Hypothesis } \\
\text { supported? }\end{array}$} & \multicolumn{2}{|c|}{ Significance (p) } \\
\hline & $\mathrm{D}$ & $\mathrm{S}$ & D & $\mathrm{S}$ & D & S \\
\hline $\mathrm{PE} \rightarrow \mathrm{BI}$ & .151 & .353 & Yes & Yes & $<0.05$ & $<0.01$ \\
\hline $\mathrm{EE} \rightarrow \mathrm{BI}$ & .050 & -.018 & No & No & Ns & Ns \\
\hline $\mathrm{SI} \rightarrow \mathrm{BI}$ & -.172 & -.025 & No & No & $<0.05$ & Ns \\
\hline $\mathrm{FC} \rightarrow \mathrm{BI}$ & .103 & .155 & No & No & Ns & Ns \\
\hline $\mathrm{ANX} \rightarrow \mathrm{BI}$ & .026 & .018 & No & No & Ns & Ns \\
\hline $\mathrm{AT} \rightarrow \mathrm{BI}$ & .862 & .421 & Yes & Yes & $<0.001$ & $<0.001$ \\
\hline $\mathrm{R}^{2}(\mathrm{BI})$ & .933 & .673 & & & & \\
\hline
\end{tabular}

Legend: Ns=not significant

This study analyzed the interaction effects of two moderating variables, age (AGE) and length of work experience (LWE), on selected exogenous variables to the endogenous variable. Analysis was done using bootstrapping procedure in partial least square SEM. Researchers have suggested an interpretation of effect sizes: from 0.02 as weak, from 0.15 as moderate, and above 0.35 as strong [67].

The tests for moderating effects of age (AGE) revealed that it has no effect on effort expectancy in both the Davao and Surabaya samples. Age strongly and positively moderates the effect of anxiety on behavioral intention of the Davao sample, whereas it has no moderating effect for the Surabaya sample. Age does not appear to affect the association between attitude and behavioral intention of Davao and Surabaya city government employees.

The study found out that length of work experience (LWE) does not affect the performance expectancy of both Davao and Surabaya respondents. While it does not influence the associations between effort expectancy, social influence and behavioral intention of Surabaya respondents, it strongly moderates in the negative direction the associations between effort expectancy, social influence, and behavioral intention of Davao respondents. Length of work experience of both Davao and Surabaya respondents does not affect their attitudes towards adopting organizational structuring.

\section{CONCLUSIONS}

This study sought to ascertain: firstly, what variables are associated with the intention of local government employees to adopt organizational structuring for ICTenabled government; and secondly, whether their age and length of work experience moderate these associations. Based on the research model, the findings show that performance expectancy and attitude are the pivotal factors for adopting organizational structuring by employees of the Davao and Surabaya city governments. It also shows that there are no associations between the other variables, i.e. effort expectancy, social influence, facilitating conditions, anxiety, and intention to adopt organizational structuring.

Age appears to significantly moderate the positive association between anxiety and behavioral intention of the Davao sample, which implies that older employees tend to be anxious about adopting organizational structuring. Moreover, findings imply that employees who have worked relatively longer in the Davao city government had a tendency to suppose that adopting organizational structuring would require more effort, and to assume that social influences or factors are not important considerations in adopting organizational structuring.

\section{RECOMMENDATIONS}

For e-government transformation to be adoptable and efficacious, some conditions are necessary. Transforming so as to improve the city government's performance, hence become more effective and efficient, should always be instilled among the employees through regular orientations or seminars. The employees should be made to understand that doing so requires additional effort on their part being members of the organization. Moreover, they should also be made to realize that while technology is rapidly improving, at 
the same time citizens' expectations of government service delivery are also rising and therefore adjustments have to be done. City government officials and decisionmakers should see to it that financial, technical, and structural support are present through enactment of appropriate local policies. This necessitates sound political leadership and committed political will from city officials. The positive attitude towards the idea and practice of transformational government should be maintained and sustained among city government employees and officials, especially among the older ones.

Appendix 1. Recent e-government adoption literature

\begin{tabular}{|c|c|c|c|}
\hline Author/s & $\begin{array}{l}\text { Variables or key } \\
\text { concepts }\end{array}$ & $\begin{array}{l}\text { Adoption or } \\
\text { use target }\end{array}$ & $\begin{array}{l}\text { Sample } \\
\text { population }\end{array}$ \\
\hline $\begin{array}{l}\text { Hung, S. -Y., } \\
\text { Tang, K. -Z., } \\
\text { Chang, C. - } \\
\text { M., \& Ke, C. } \\
\text {-D. (2009) } \\
\text { [68] }\end{array}$ & $\begin{array}{l}\text { perceived } \\
\text { usefulness, } \\
\text { perceived ease of } \\
\text { use, training, } \\
\text { compatibility, } \\
\text { external influence, } \\
\text { interpersonal } \\
\text { influence, self- } \\
\text { efficacy, } \\
\text { facilitating } \\
\text { conditions }\end{array}$ & $\begin{array}{l}\text { electronic } \\
\text { document } \\
\text { management } \\
\text { system }\end{array}$ & $\begin{array}{l}\text { Government } \\
\text { employees }\end{array}$ \\
\hline $\begin{array}{l}\text { Aboelmaged, } \\
\text { M. G. (2010) } \\
{[69]}\end{array}$ & $\begin{array}{l}\text { perceived } \\
\text { usefulness, } \\
\text { subjective norm, } \\
\text { attitude, social } \\
\text { influence, } \\
\text { behavioral } \\
\text { intention }\end{array}$ & $\begin{array}{l}\mathrm{e}- \\
\text { procurement }\end{array}$ & $\begin{array}{l}\text { Supply chain } \\
\text { partners }\end{array}$ \\
\hline $\begin{array}{l}\text { Lin, F., } \\
\text { Fofanah, S. } \\
\text { S., \& Liang, } \\
\text { D. (2011) } \\
\text { [70] }\end{array}$ & $\begin{array}{l}\text { attitude, perceived } \\
\text { usefulness, } \\
\text { perceived ease of } \\
\text { use, information } \\
\text { system quality, } \\
\text { information } \\
\text { quality, behavioral } \\
\text { intention }\end{array}$ & $\begin{array}{l}\text { e- } \\
\text { government } \\
\text { initiatives } \\
\text { (not } \\
\text { specified) }\end{array}$ & Citizen-users \\
\hline $\begin{array}{l}\text { Carter, L., } \\
\text { Schaupp, L. } \\
\text { C., Hobbs, J., } \\
\text { \& Campbell, } \\
\text { R. (2012) } \\
\text { [71] }\end{array}$ & $\begin{array}{l}\text { performance } \\
\text { expectancy, social } \\
\text { influence, } \\
\text { facilitating } \\
\text { conditions, } \\
\text { optimism bias, } \\
\text { perceived } \\
\text { reputation, } \\
\text { perceived risk }\end{array}$ & e-tax filing & $\begin{array}{l}\text { Citizen- } \\
\text { taxpayers }\end{array}$ \\
\hline $\begin{array}{l}\text { Bonsón, E., } \\
\text { Torres, L., } \\
\text { Royo, S., \& } \\
\text { Flores, F. } \\
\text { (2012) [72] }\end{array}$ & $\begin{array}{l}\text { Sophistication } \\
\text { index, public } \\
\text { administration } \\
\text { style }\end{array}$ & $\begin{array}{l}\text { Web } 2.0 \text { and } \\
\text { social media }\end{array}$ & $\begin{array}{l}\text { Local } \\
\text { governments }\end{array}$ \\
\hline $\begin{array}{l}\text { Weerakkody, } \\
\text { V., El- } \\
\text { Haddadeh, } \\
\text { R., Al-Sobhi, } \\
\text { F., Shareef, } \\
\text { M. A., \& } \\
\text { Dwivedi, Y. } \\
\text { K. (2013) } \\
\text { [73] }\end{array}$ & $\begin{array}{l}\text { performance } \\
\text { expectancy, effort } \\
\text { expectancy, social } \\
\text { influence, } \\
\text { facilitating } \\
\text { conditions, trust of } \\
\text { the internet, trust } \\
\text { of intermediary, } \\
\text { behavioral } \\
\text { intention, usage } \\
\text { behavior }\end{array}$ & $\begin{array}{l}\text { e- } \\
\text { government } \\
\text { services (not } \\
\text { specified) }\end{array}$ & Citizen-users \\
\hline $\begin{array}{l}\text { Hung, S. -Y., } \\
\text { Chang, C. - } \\
\text { M., \& Kuo, } \\
\text { S.-R. (2013) }\end{array}$ & $\begin{array}{l}\text { perceived } \\
\text { usefulness, } \\
\text { perceived ease of } \\
\text { use, trust, }\end{array}$ & $\begin{array}{l}\text { Mobile e- } \\
\text { government } \\
\text { services (not } \\
\text { specified) }\end{array}$ & Citizen-users \\
\hline
\end{tabular}

\begin{tabular}{|c|c|c|c|}
\hline [74] & $\begin{array}{l}\text { interactivity, } \\
\text { external influence, } \\
\text { interpersonal } \\
\text { influence, self- } \\
\text { efficacy, } \\
\text { facilitating } \\
\text { conditions }\end{array}$ & & \\
\hline $\begin{array}{l}\text { Alryalat, } \\
\text { M.A.A., } \\
\text { Rana, N. P., } \\
\text { \& Dwivedi, } \\
\text { Y. K. (2015) } \\
\text { [75] }\end{array}$ & $\begin{array}{l}\text { perceived } \\
\text { usefulness, } \\
\text { perceived trust, } \\
\text { self-efficacy, } \\
\text { attitude, subjective } \\
\text { norm }\end{array}$ & $\begin{array}{l}\text { online PAN } \\
\text { card } \\
\text { registration } \\
\text { system }\end{array}$ & Citizen-users \\
\hline $\begin{array}{l}\text { Rana, N. P., } \\
\text { Dwivedi, Y. } \\
\text { K., Williams, } \\
\text { M. D., \& } \\
\text { Weerakkody, } \\
\text { V. (2016) } \\
\text { [76] }\end{array}$ & $\begin{array}{l}\text { performance } \\
\text { expectancy, effort } \\
\text { expectancy, social } \\
\text { influence, } \\
\text { facilitating } \\
\text { conditions, } \\
\text { anxiety, attitude, } \\
\text { behavioral } \\
\text { intention }\end{array}$ & $\begin{array}{l}\text { Online public } \\
\text { grievance } \\
\text { redressal } \\
\text { system }\end{array}$ & Citizen-users \\
\hline $\begin{array}{l}\text { Dwivedi, } \\
\text { Y.K., Rana, } \\
\text { N.P., } \\
\text { Janssen, M., } \\
\text { Lal, B., } \\
\text { Williams, } \\
\text { M.D., \& } \\
\text { Clement, M. } \\
\text { (2017) } \\
\text { [77] } \\
\end{array}$ & $\begin{array}{l}\text { performance } \\
\text { expectancy, effort } \\
\text { expectancy, social } \\
\text { influence, } \\
\text { facilitating } \\
\text { conditions, } \\
\text { perceived risk, } \\
\text { attitude, } \\
\text { behavioral } \\
\text { intention } \\
\end{array}$ & $\begin{array}{l}\text { online } \\
\text { permanent } \\
\text { account } \\
\text { number card } \\
\text { registration } \\
\text { system }\end{array}$ & Citizen-users \\
\hline
\end{tabular}

Appendix 2. Indicators of variables

\begin{tabular}{|c|c|}
\hline Variables & Indicators \\
\hline \multirow[t]{4}{*}{$\begin{array}{l}\text { Performance } \\
\text { expectancy (PE) }\end{array}$} & $\begin{array}{l}\text { PE1 completion of tasks in less time } \\
\text { and at less cost }\end{array}$ \\
\hline & $\begin{array}{l}\text { PE2 achievement of set goals and } \\
\text { objectives }\end{array}$ \\
\hline & PE3 enhancement of service quality \\
\hline & PE4 increase overall productivity \\
\hline \multirow{4}{*}{$\begin{array}{l}\text { Effort expectancy } \\
\text { (EE) }\end{array}$} & EE1 implementing would be easy \\
\hline & EE2 using or adopting would be easy \\
\hline & $\begin{array}{l}\text { EE3interaction with co-workers } \\
\text { would be unproblematic }\end{array}$ \\
\hline & $\begin{array}{l}\text { EE4 adjustment would be } \\
\text { uncomplicated }\end{array}$ \\
\hline \multirow[t]{4}{*}{$\begin{array}{l}\text { Social influence } \\
\text { (SI) }\end{array}$} & $\begin{array}{l}\text { SI1 must be done because other cities } \\
\text { are doing it }\end{array}$ \\
\hline & $\begin{array}{l}\text { SI2 must be done because other } \\
\text { departments/divisions are doing it }\end{array}$ \\
\hline & $\begin{array}{l}\text { SI3 must be done because citizens } \\
\text { expect it }\end{array}$ \\
\hline & $\begin{array}{l}\text { SI4 must be done because citizens } \\
\text { demand it }\end{array}$ \\
\hline \multirow[t]{4}{*}{$\begin{array}{l}\text { Facilitating } \\
\text { conditions (FC) }\end{array}$} & $\begin{array}{l}\text { FC1 having the knowledge and skill } \\
\text { to use it }\end{array}$ \\
\hline & $\begin{array}{l}\text { FC2 technical support and assistance } \\
\text { would be available }\end{array}$ \\
\hline & FC3 financial support is available \\
\hline & FC4 city administration supports it \\
\hline \multirow[t]{4}{*}{ Anxiety (ANX) } & $\begin{array}{l}\text { ANX1 feeling of hesitancy in using or } \\
\text { doing it }\end{array}$ \\
\hline & $\begin{array}{l}\text { ANX } 2 \text { feeling of worry that it will not } \\
\text { work out as expected }\end{array}$ \\
\hline & $\begin{array}{l}\text { ANX3 feeling of being overwhelmed } \\
\text { by it }\end{array}$ \\
\hline & $\begin{array}{l}\text { ANX4 feeling of concern that citizens } \\
\text { will not like it }\end{array}$ \\
\hline \multirow{4}{*}{ Attitude (AT) } & AT1 it is a good idea \\
\hline & AT2 it is a worthwhile thing to do \\
\hline & AT3 it is likeable \\
\hline & AT4 it is nice \\
\hline \multirow{2}{*}{$\begin{array}{l}\text { Behavioral } \\
\text { intention (BI) }\end{array}$} & BI1 intending to do it \\
\hline & BI2 predicting that one would do it \\
\hline
\end{tabular}


(Venkatesh, et al. $\quad$ BI3 planning to do it very soon 2003) [78]

\section{REFERENCES}

[1] United Nations Department of Economic and Social Affairs [UNDESA] (2004). Global egovernment readiness report 2004. New York: United Nations.

[2] United Nations Department of Economic and Social Affairs [UNDESA] (2014). United Nations e-government survey 2014: E-government for the future we want. New York: United Nations.

[3] Falk, S. (2011). The rise of the digital citizen. Policy Advice and Political Consulting Vol. 4 No. 4 (Nomos Verlagsgesellschaft $\mathrm{mbH}$ ) accessed 22-02-2016

http://www.jstor .org/stable/24234856

[4] Bannister F. \& Connolly, R. (2012). Defining e-Governance. e-Service Journal Vol. 8 No. $2 . \quad$ Indiana University Press. accessed 22-022016

[5] van der Meer, T. Gelders, D. \& Rotthier, S. (2014). e-democracy: Exploring the current stage of egovernment. Journal of Information Policy Vol. 4. Penn State University Press. accessed 22-02-2016. http://www.jstor.org/stable/10.5325/i infopoli.4.2014.0489

[6] UNDESA, 2014, op. cit.

[7] Weerakkody, V. Janssen, M. \& Dwivedi, Y. K. (2011). Transformational change and business process reengineering (BPR): Lessons from the British and Dutch public sector. Government
Information Quarterly 28, 2011. Elsevier.

[8] Layne, K. \& Lee, J. (2001). Developing fully functional egovernment: A four stage model. Government Information Quarterly, Vol. 18 No. 2.

[9] Hiller, J. S., \& Belanger, F. (2001). Privacy strategies for electronic government. E-Government 200.

[10] Wescott, C. G. (2001). Egovernment in the Asia-Pacific region. Asian Journal of Political Science Vol. 9 No. 2.

[11] Moon, M. J. (2002) The evolution of e-government among municipalities: Rhetoric or reality? Public Administration Review Vol. 62 No.4.

[12] West, D. M. (2004). E-government and the transformation of service delivery and citizen attitudes.

Public Administration Review Vol. 64 No.1.

[13] Cisco IBSG (2007) e-Government Best Practices: Learning from Success, Avoiding the Pitfalls.

Retrieved from http://siteresources.worldbank.org/E XTEDEVELOPMENT/Resources/20 0802

22_Phil_eGovworkshop.pdf?resourc eurlname=20080222_Phil_eGov_wo rkshop.pdf

[14] Alhomod, S. M., Shafi, M. M., Kousarrizi, M. N., Seiti, F., Teshnehlab, M., Susanto, H. \& Batawi, Y. A. (2012). Best practices in e-government: A review of some innovative models proposed in different countries. International Journal of Electrical \& Computer Sciences, Vol. 12 No. 01. 
[15] United Nations Department of Economic and Social Affairs [UNDESA] (2003). World public sector report: E-government at the crossroads. New York: United Nations.

[16] United Nations Department of Economic and Social Affairs [UNDESA] (2014). United Nations e-government survey 2014: E-government for the future we want. New York: United Nations.

[17] ibid.

[18] ibid.

[19] Obi, T. \& Iwasaki, N. (2015). A Decade of World e-Government Rankings. Netherlands: IOS Press.

[20] Weerakkody, V. Janssen, M. \& Dwivedi, Y. K. (2011). Transformational change and business process reengineering (BPR): Lessons from the British and Dutch public sector. Government Information Quarterly 28, 2011. Elsevier.

[21] Hammer, M. \& Champy, J. (1993). Re-engineering the cooperation: A manifesto for business revolutions. New York: Harper Business.

[22] Weerakkody, et al. op. cit.

[23] ibid.

[24] Hammer \& Champy, op.cit.

[25] UNDESA, 2014, op. cit.

[26] Obi and Iwasaki, op. cit.

[27] Nurmandi, A. \& Kim, S. (2015). Making e-procurement work in a decentralized procurement system: A comparison of three Indonesian cities. International Journal of Public Sector Management Vol. 28 Issue 3. Emerald Insight.

[28] Kim, S. Kim H. J. \& Lee, H. (2009). An institutional analysis of an egovernment system for anticorruption: The case of OPEN. Government Information Quarterly, $262009 . \quad$ Elsevier Inc.

[29] D'Agostino, M. Schwester, R. Carrizales, T. \& Melitski, J. (2011). A study of e- government and egovernance: An empirical examination of municipal websites. Public Administration Quarterly Vol. 35 No. 1 Spring 2011 SPAEF.

[30] Rana, N. P. Dwivedi, Y. K. \& Williams, M. D. (2013). Egovernment adoption research: An analysis of the employee's perspective. International Journal of Business Information Systems, Vol. 14 No. 4.

[31] Venkatesh, V. Morris, M. G. Davis, G. B. \& Davis, F. D. (2003). User acceptance of information technology: Toward a unified view. MIS Quarterly 27 (3).

[32] Al-Gahtani, S., Hubona, G. \& Wang, J. (2007). Information technology (IT) in Saudi Arabia: Culture and the acceptance and use of IT. Information \& Management 44. Elsevier.

[33] Chan, F. Thong, J. Venkatesh, V. Brown, S. Hu, P. J. \& Tam, K. (2010). Modeling citizen satisfaction with mandatory adoption of an e-government technology. Journal of the Association for Information Systems Vol. 11 Issue 10 519-549. 
[34] Gupta, B. Dasgupta, S. \& Gupta, A. (2008). Adoption of ICT in a government organization in a developing country: An empirical study. Journal of Strategic Information Systems 17 140-154. Elsevier.

[35] Ajzen, I. \& Fishbein, M. (1980). Understanding attitudes and predicting social behavior. Englewood, Cliff, NJ: Prentice-Hall.

[36] ibid.

[37] Ajzen, I. (1991). The theory of planned behavior. Organizational Behavior and Human Decision Processes 50 (2).

[38] Compeau, D. R., \& Higgins, C. A. (1995) Computer Self-Efficacy: Development of a Measure and Initial Test. MIS Quarterly (19) (2) 189-211.

[39] Venkatesh, et al., 2003, op. cit.

[40] Carter, L. \& Bélanger, F. (2005). The utilization of e-government services: Citizen trust, innovation and acceptance factors. Info Systems Journal 15 5-25.

[41] Stamati, T. Papadopoulos, T. \& Martakos, D. (2011). Transformational government citizens' services adoption: A conceptual framework. In M. Janssen et al. (Eds.) EGOV 2011 LNCS 6846, 134-143. IFIP International Federation for Information Processing.

[42] Venkatesh, et al., 2003, op. cit.

[43] ibid.

[44] Ajzen, 1991, op. cit.
[45] Hung, S.Y., Tang, K.Z., Chang, C.M., \& Ke, C. D. (2009). User acceptance of intergovernmental services: an example of electronic document management system. Government Information Quarterly 26(2) 387-397.

[46] Lu, C.T. Huang, S.Y. \& Lo, P. Y. (2010). An empirical study of on-line tax filing acceptance model: integrating TAM and TPB. African Journal of Business Management 4(5) 800-810.

[47] Hung, S.Y. Chang, C.M. \& Kuo, S. R. (2013). User acceptance of mobile e-government services: an empirical study. Government Information Quarterly 30(1) 33-44.

[48] Rana, N. P. Dwivedi, Y. K. \& Williams, M. D. (2015). A metaanalysis application for synthesizing findings of existing research on citizen adoption of eGovernment. Information Systems Frontiers 17(3) 547-56.

[49] Baron, R. M. \& Kenny, D. A. (1986). The moderator-mediator variable distinction in social

psychological research: conceptual, strategic, and statistical considerations. Journal of Personality and Social Psychology, 51(1) 1173-1182.

[50] Henseler, J., \& Fassott, G. (2010). Testing moderating effects in PLS path models: An illustration of available procedures. In V. E. Vinzi et al. (Eds.), Handbook of Partial Least Squares, Springer Handbooks of Computational Statistics. DOI 10.1007/978-3- 540-32827-

8_31, (Springer-Verlag Berlin Heidelberg).

[51] Venkatesh, V. \& Morris, M. G. (2000). Why don't men ever stop to ask for directions? Gender, social 
influence and their role in technology acceptance and usage behavior. MIS Quarterly 24 (1), 115-139.

[52] Venkatesh, et al., 2003, op. cit.

[53] Rana, et al., 2013, op cit.

[54] Dick, H. W. (2003) Surabaya, City of Work: A Socioeconomic History 1900-2000. Singapore: NUS Press.

[55] Adnani, A. (2014). IT value analysis for public sector: Case study of Surabaya City. 2014 International Conference on Information Technology and Innovation ICTSI (Bandung: IEEE).

[56] Prahono, A.\& Elidjen (2015). Evaluating the role of e-government on public administration reform: Case of official city government websites in Indonesia. Procedia Computer Science 59 2015. Elsevier B.V.

[57] Nadjib, U. Thoyib, A. Sukarnoto \& Otok, B. W. (2014). E-government moderator in reliability on satisfaction and its implications toward citizen loyalty in government public service of Surabaya City. International Journal of Academic Research Vol. 6 No. 5. EBSCO.

[58] Catubig, M. C. Villano, R. \& Dollery, B. (2015). Payment schemes in conditional cash transfer programs: The case of 4Ps in the Davao Region, Philippines. Administrative Sciences Vol. 5 Issue 4. Open Access.

[59] UNDESA, 2014, op. cit.

[60] Vega, L. J. (2015). Transforming Health Care Services. Southern Philippines Medical Center
Journal of Health Services Vol. 1 No. 1 2015. Davao City: SPMC.

[61] Obi \& Iwasaki, op cit.

[62] Vagias, W. M. (2006). Likert-type Scale Response Anchors. Clemson International Institute for Tourism \& Research Development, Department of Parks, Recreation and Tourism Management. Clemson University.

[63] Henseler, J., Ringle, C. \& Sinkovics, R. (2009). The use of partial least squares path modeling in international marketing. Advances in International Marketing, 20, 277-320

[64] Urbach, N., \& Ahlemann, F. (2010). Structural equation modeling in information systems research using partial least squares. Journal of Information Technology Theory and Application, 11(2), 5-40.

[65] ibid.

[66] Chin, W. (1998). The partial least squares approach to structural equation modeling. In G. A. Marcoulides (Ed.), Modern Methods for Business Research (295358). Mahwah, NJ: Lawrence Erlbaum Associates.

[67] Henseler \& Fassot, op. cit.

[68] Hung, S. -Y., Tang, K. -Z., Chang, C. -M., \& Ke, C. -D. (2009). User acceptance of intergovernmental services: An example of electronic document management system.

Government Information Quarterly, 26(2), 387-397.

[69] Aboelmaged, M.G. (2010) Predicting e- procurement adoption in a developing country: An empirical integration of technology 
acceptance model and theory of planned behavior. Industrial Management \& Data Systems, Vol. 110 Issue: $3,392-414$.

[70] Lin, F., Fofanah, S. S., \& Liang, D. (2011). Assessing citizen adoption of e-government initiatives in Gambia: A validation of the technology acceptance model in information systems success. Government Information Quarterly, 28(2), 271279.

[71] Carter, L., Schaupp, L. C., Hobbs, J., \& Campbell, R. (2012). Egovernment utilization: Understanding the impact of reputation and risk. International Journal of Electronic Government Research, 8(1), 83-97.

[72] Bonsón, E., Torres, L., Royo, S., \& Flores, F. (2012). Local egovernment 2.0: Social media and corporate transparency in municipalities. Government Information Quarterly, 292, 123132.

[73] Weerakkody, V., El-Haddadeh, R., Al-Sobhi, F., Shareef, M. A., \& Dwivedi, Y. K. (2013). Examining the influence of intermediaries in facilitating e-government adoption: An empirical investigation. International Journal of Information Management, 33(5), 716-725.

[74] Hung, S. -Y., Chang, C. -M., \& Kuo, S. -R. (2013). User acceptance of mobile e-government services: An empirical study. Government Information Quarterly, 30(1), 33-44.

[75] Alryalat, M.A.A., Rana, N. P., \& Dwivedi, Y. K. (2015). Citizen's adoption of an e-government system:
Validating extended social cognitive theory (SCT). Government Information Quarterly, 32(2), 172-181.

[76] Rana, N. P., Dwivedi, Y. K., Williams, M. D., \& Weerakkody, V. (2016). Adoption of online public grievance redressal system in India: Toward developing a unified view. Computers in Human Behavior, 59, 265-282.

[77] Dwivedi, Y.K., Rana, N.P., Janssen, M., Lal, B., Williams, M.D., \& Clement, M. (2017). An empirical validation of a unified model of electronic government adoption (UMEGA), Government Information Quarterly (2017), http://dx.doi.org/10.1016/j.giq.2017. 03.001

[78] Venkatesh, et al., 2003, op. cit. 